\title{
1. Introduction: River as Ethnographic Subject
}

\section{JOHN R. WAGNER, JERRY K, JACKA, EDVARD HVIDING, ALEXANDER MAWYER AND MARAMA MURU-LANNING}

Our intention in this volume is to make an original and innovative contribution to the ethnographic record of Oceania while also contributing to global debates about rivers and fresh water. Given the historical tendency for human societies everywhere to situate themselves near rivers, lakes, streams and other sources of fresh, flowing water, one might expect to find abundant, detailed descriptions of rivers in the early ethnographic record. But this is not the case.

Before 1950, when anthropological publications focused specifically on fresh water, the topic was most often folkloric in nature, about water beings, water divining or water symbolism (e.g. Hongi 1894; Holmes 1898; Piddington 1930). References to rivers as geographic markers were also very common, as when Murray and Ray (1918) published their article on 'The People and Language between the Fly and Strickland Rivers, Papua', but articles that actually describe rivers are rare indeed. Arthur Hayes (1906) published a description of the people of Abyssinia in a book entitled The Source of the Blue Nile, but wrote almost nothing about the river itself or about the riverine adaptations of the people he described. A 1912 article by Emmons about the Kitselas of British Columbia 
is exceptional, by comparison to most of the literature of that period, by virtue of its detailed environmental and, at times, poetic description of the river and its people:

Where the Skeena River breaks through the eastern barrier of the Coast Range in British Columbia, 75 miles from its mouth, the pent-up waters have cut a deep cañon upward of a mile and a half in length, impassable during the spring and summer freshets and fraught with danger at all seasons. It is the most justly dreaded inland waterway of the Northwest, for, aside from the tremendous force of the contracted river over an uneven rocky bottom, forming great swirls and riffles, the upper entrance is obstructed by two high, narrow, rock ridges that divide the waters, forming two narrow channels at all stages and a third at extreme high water ... The natives named this part of the river cañon Dsilasshoo, and those who lived here as Gitdsilasshoo, "people of the cañon," but this is now written officially Kitselas. (Emmons 1912: 467-8)

By the middle of the twentieth century, however, water-and rivers in particular-came to occupy a more prominent place in the anthropological canon, as evidenced by the work of Julian Steward and others who were interested in the relationship of water to agriculture and political organisation. Steward published a seminal article about the role of irrigation in the development of 'ancient civilisations' in China, Mesopotamia, Peru and Mesoamerica in 1949. In 1955, with contributions from Karl Wittfogel and other authors, he published Irrigation Civilizations, a work that pre-dated Wittfogel's subsequently more influential work on 'hydraulic societies' (Wittfogel 1956, 1957). Steward and Wittfogel used mainly historical rather than ethnographic evidence to construct their theories, but ethnographic studies of irrigation systems also became prominent in the 1950s and have increased every decade since then. Thus, by mid-century, the field we now call the 'anthropology of water' came to be focused mainly on the value of water as a political and economic 'resource' rather than on its mythological and symbolic qualities (e.g. Geertz 1972). The post-war economic boom of the 1950s, '60s and early '70s, fuelled in part by the construction of ever more and larger hydro-power dams and massive irrigation diversions, consolidated this focus. The even more rapid pace of globalisation, population growth, urbanisation and agricultural intensification since the 1970s has led to a further re-inscription of rivers and fresh water, not just as a 'resource', but as a 'scarce resource' and 'commodity' (Bakker 2003; Strang 2004; Mehta 2005; Wagner 2012). 
Though Steward's and Wittfogel's early theorising was deeply flawed in many of its details, especially in its tendency towards over-generalisation and deterministic arguments, scholars with diverse disciplinary backgrounds continue to make use of their general hypothesis about hydraulic societies' (see Worster 1985). However, the most nuanced contemporary studies of water in relation to political and economic organisation tend to avoid over-generalisations and focus on a much wider variety of historical settings and issues (e.g. Davis 1996, 2013; Donahue and Johnston 1997; Mosse 2003; Strang 2004, 2009; Baviskar 2007; Lahiri-Dutt and Samanta 2013; Wagner 2013; Hastrup and Hastrup 2016). Climate change adds yet more intensity and urgency to the anthropological study of water (Crate and Nuttall 2009; Hastrup 2009, Hastrup and Skrydstrup 2013; Orlove 2009), and converges with studies that focus on water as a human right (Sultana and Loftus 2012; Hossen 2014) and water and health (Whiteford and Whiteford 2005).

Not surprisingly, most anthropological studies of water over the past few decades have been carried out by political ecologists, but the interest in water has now expanded well beyond the set of interests and perspectives that define that field. This has given rise to a rich, diverse and even chaotic body of work that is also increasingly interdisciplinary. Some of the themes that attracted the interest of early anthropologists, such as myth and symbolism, are attracting renewed interest, but the attraction is now less folkloric than epistemological and ontological (e.g. Carse 2010; Krause 2010; Edgeworth 2011; Helmreich 2009; Strang 2014, 2016; Hastrup and Hastrup 2016; see also the contributions to this volume). As Hastrup and Hastrup write in their introduction to Waterworlds, 'anthropology now finds itself at a moment in time when the field is literally wide open', where 'there is no given anthropological object, but multiple and composite objects', and where 'fluidity on all accounts is the order of the day' (2016: 2). They apply their comments not just to the anthropology of water but to anthropology as a whole in an 'anthropocene era'.

The chapters in this volume are organised around the notion that rivers have social lives and therefore merit thorough ethnographic investigation and description. ${ }^{1}$ Water is social by virtue of the fact that it flows through

1 There has been a curious proliferation of book titles recently that attribute social lives to a whole host of animate and inanimate beings. The trend appears to have begun with Appadurai's (1986) The Social Life of Things, a study of commodities, but has more recently been applied to 'trees' (Rival 1998), 'information' (Brown and Duguid 2000), 'coffee' (Cowan 2005), 'numbers' (Urton 2010), 'science' (Hastrup 2012), 'water' (Wagner 2013) and 'climate change models' (Hastrup and Skrydstrup 2013). 
and animates all aspects of human life, not just at the cellular level but as a 'total social fact' in the sense proposed by Orlove and Caton (2010; see also Krause and Strang 2016). Using the term 'social' in its broadest sense to include political institutions, economic behaviour and cultural and religious practices, it is readily apparent that water informs every dimension of human social behaviour and is essential to the ways in which we construct class, gender and kinship. ${ }^{2}$

If one begins with the premise that rivers are fundamentally social in nature, then it is possible to treat rivers as the 'subject' rather than the 'object' of investigation. We are not collectively espousing a post-humanist approach to water, or an approach that depends on the argument that water possesses agency, though some contributors to this volume (e.g. Wagner, Jacka and Torgersen) are sympathetic to one or both of these approaches. Arguments about the agency of water are based on several distinct lines of thought, most of which are consistent with, but not essential to, the idea of rivers as ethnographic subjects. Scholars who adopt a posthumanist approach to their treatment of the non-human, for instance, argue that agency should not be defined in ways that restrict it to human beings. To do so, they argue, reinforces an anthropocentric approach that has imperilled the world, through pollution, over-exploitation of non-renewable resources, loss of biodiversity, climate change and other anthropogenic impacts. Actor-network theorists are also strong advocates for an approach that assigns agency to the non-human, defining agency not in terms of human intentionality, but in terms of measurable impacts within material-semiotic networks that include non-human as well as human actors. Other scholars embrace an animistic worldview in which all of nature is imbued with spirit and therefore intentionality and agency as well.

A recent publication by Strang (2014), with responses from several other scholars, effectively summarises many of the arguments for and against the agency of things. In this introduction, we would like to draw attention to two lines of argument not fully developed in that volume. The first of these is based on the work of Tim Ingold, who argues that the idea of nonhuman agency, despite its merits, is inherently self-contradictory. Strang (2014: 135) notes that Ingold's approach is consistent with 'a theoretical shift towards less anthropocentric visions of human-environmental

2 See also Strang (2004: 3-6) on the 'essentiality' of water. 
interactions' and 'a more egalitarian bioethic of relationality', but that he nevertheless rejects the notion that things possess agency. Ingold argues that the 'problem of agency' is one we have created for ourselves:

[It is] born of the attempt to re-animate a world already rendered lifeless by an exclusive focus on the 'objectness' of things ... It is indeed striking that the more theorists have to say about agency, the less they seem to have to say about life. To rewrite the life of things as the agency of objects is to effect a double reduction, of things to objects, and of life to agency. (Ingold 2010: 97)

Ingold's argument did not directly inform our collective approach to this volume but it is very consistent with our intent. Our goal is to treat rivers as subjects rather than objects, and to shed light on the ways in which human lives in Oceania are interwoven with the lives of rivers, the landforms through which they flow and the other species they sustain.

A second line of argument not discussed in Strang (2014), but pertinent to this volume, has been developed by Salmond in her account of how the Whanganui River in New Zealand came to be recognised in law as a 'living being'. The Whanganui River is one of the first rivers in the world - though surprisingly not the only one - to have attained this status (Salmond 2014: 285-6). This was accomplished through the negotiation of a deed of settlement between the Māori and the New Zealand Government, known in Māori as Ruruku Whakatupua. In conferring 'legal personhood' on the river, Whanganui Māori are able to speak for their river in the country's courts and to file lawsuits on its behalf when environmental protections are not upheld. This approach is a type of modern co-management, through which the rights and health of the river are upheld through shared decision-making involving local Māori and other resident communities. Concerning the divergent understandings of the river held by Māori and non-Māori, Salmond writes:

In the Whanganui deed of settlement with the Crown, ancestral Māori and modernist framings are juxtaposed, despite being incommensurable in certain respects. Drawing upon divergent forms of order, participants in the process have sought to weave together a concerted approach toward the management of New Zealand's waterways. This interweaving avoids the need for a merging of horizons, a "theory of everything" in which only one reality is possible and only one set of assumptions about the world can prevail. (Salmond 2014: 285) 
Despite the fact that Salmond never cites Ingold in her paper, she concludes by articulating a position that seems very consistent with his, and also with the work of Bennett (2010), whom she does cite:

In the Pacific and elsewhere, it is likely that the most intransigent obstacles to solving environmental (and other) challenges lie at the level of presupposition. As Jane Bennett has argued, 'the image of dead or thoroughly instrumentalised matter feeds ... our earth-destroying fantasies of conquest and consumption' (Bennett 2010: ix-x). Thus, Homo hubris trumps Homo sapiens. In such a situation, despite scientific claims to the contrary, epistemological solutions will not work. Fundamental conceptions and forms of order will have to shift if more lasting, flourishing styles of living are to be found. Here, ontological styles in which matter has never been dead or separated from people may prove helpful. When Bennett urges us to 'picture an ontological field without unequivocal demarcations between human, animal, vegetable, or mineral' where 'all forces and flows are or can become lively [and] affective' (Bennett 2010: 116-17), I think of the nineteenth-century Māori philosopher Nepia Pohuhu, who said, 'All things unfold their nature (tupu), live (ora), have form (ähua), whether trees, stones, birds, reptiles, fish, quadrupeds or human beings' (Pohuhu in Smith 1913: 13). (Salmond 2014: 305)

Neither Pohuhu's statement nor Salmond's argument should be read as an endorsement of animism, an idea invented by Western scholars and often misapplied to Indigenous societies around the world (Ingold 2006). The argument, rather, is about finding a way to think about rivers that is ontologically inclusive but also practical in political, economic and legal terms.

Understanding water as a subject in its own right, and not merely as 'instrumentalised matter', reinforces the distinction made by Ivan Illich (1985) between water as $\mathrm{H}_{2} \mathrm{O}$ and water as the substance of dreams. Addressing the citizens of Dallas, Texas, in 1984 about a proposal to create a downtown lake a dozen blocks in size, Illich begins by stating that: 'I shall refuse to assume that all waters may be reduced to $\mathrm{H}_{2} \mathrm{O}$ ' (1985: 4). Relying on Bachelard's (1999) Water and Dreams, which explores the primordial, archetypal and imaginative dimensions of water, Illich writes:

Following dream waters upstream, the historian will learn to distinguish the vast register of their voices. As his ear is attuned to the music of deep waters, he will hear a discordant sound that is foreign to waters, that reverberates through the plumbing of modern cities. He will recognize that the $\mathrm{H}_{2} \mathrm{O}$ which gurgles through Dallas plumbing is not water, 
but a stuff which industrial society creates. He will recognize that the twentieth century has transmogrified water into a fluid with which archetypal waters cannot be mixed. With enough money and broad powers to condemn and evict, a group of architects could very well create out of this sewage a liquid monument that would meet their own aesthetic standards. But since archetypal waters are as antagonistic to this new "stuff" as they are to oil, I fear that contact with such liquid monumentality might make the souls of Dallas's children impermeable to the water of dreams. (Illich 1985: 7)

In a more recent publication, Raffles, writing about the Amazon, also draws on Bachelard (1999) in order to emphasise the profound intimacy of the human/water relationship. He does so by discussing Bachelard's argument that 'the language of waters is a direct poetic reality', that 'murmuring waters teach birds to sing', that there is 'a continuity between the speech of water and the speech of man' (Bachelard 1983: 15, quoted in Raffles 2002: 179). Raffles' discussion recalls the earlier ethnographic work of Feld who, in an article entitled 'Waterfalls of Song', draws our attention to the ways in which the Kaluli people of Papua New Guinea create songs that imitate the flow of water. Feld writes that singing 'takes listeners on a journey that flows along local waterways and through local lands', and that 'the flow of these poetic song paths is emotionally and physically linked to the sensual flow of the singing voice' (1996: 91).

Rich ethnographic descriptions of human/river interactions can be found in many publications that do not necessarily constitute river ethnographies in the sense that we use the term here. Raffles, for instance, includes detailed descriptions of the middle Amazon where he conducted his research, but his book is a 'natural history' focused on a comparison of different constructions of Amazonian 'nature' (Raffles 2002: 7-9). Goldman (1963) provides a detailed physical description of the Cuduiarí River, a tributary of the Amazon, in his ethnography of the Cubeo people, and a thorough account of its religious significance in a more recent (2004) publication. But the river remains a supporting actor in these accounts, never the actual subject of the authors' investigation. In another study situated in Amazonia, Harris describes the floodplain adaptation of the caboclo community of Parú. He provides a rich, ethnographic description of river-based activities and excellent detail about the ecological characteristics of the floodplain, but, as he states on the opening page of his introduction, his book is about 'identity and change' (Harris 2001: 7), not about the river itself. 
But river ethnographies in the sense that we use the term here, though still small in number, are becoming more common. Krause's recent (2010) study of the Kemi River in Finland is a prime example. He organised his study around the river itself, rather than a specific community or issue, and focused on the ways in which diverse individuals and communities participated in three dominant river activities-fishing, transportation and hydro-power generation. One of his main goals was to answer the question of whether 'river dwellers' in this setting 'think like a river'. 'To what extent', he asks, 'do the river and its flow pervade the imagination of those whose livelihoods are connected to its waters or along its banks?' (Krause 2010: 14)

In her study of the Murray River in Australia, Jessica Weir focuses on the relationships to the river of Indigenous people who see it as the heartbeat of a 'sentient ecology' (Weir 2009: 50, citing Anderson 2000: 116). Settler culture descendants, by contrast, whom Weir refers to as 'the moderns', view the river mainly as an economic resource. She also notes that the Murray Lower Darling Rivers Indigenous Nations are now calling for Indigenous water allocations based on the principle of 'cultural flows', meaning the amount of water required for them to maintain traditional cultural practices in all seasons (Weir 2009: 119).

Jessica Barnes takes a still different approach in Cultivating the Nile, an ethnographic study that emphasises the complex political and technological processes that determine how and when water will be delivered to farmers' fields in Fayoum Province, Egypt. 'This is a story about water politics', she writes, 'that takes the water itself, and the many ways in which that water is manipulated, as its beginning' (Barnes 2014: x). But, in addition to her focus on the quotidian water experiences of Fayoum farmers, she also seeks to trace the international dynamics of the Nile Basin.

It is through close ethnographic observation of how people interact with water on a day-to-day basis that I am able to access the politics of the everyday. But I do not limit the view to Egypt alone. Rather, I situate this detailed, on-the-ground analysis within the context of processes, institutions, and technologies operating outside the nation's borders, which also affect how the water of the Nile flows into and through Egypt. Thus my analysis moves back and forth across space, shifting the gaze from downstream to upstream, farmer to donor agency, local to global, international water conference to irrigation canal. (ibid.: $\mathrm{x}$ ) 
Dancing with the River, another recent book-length river ethnography by Lahiri-Dutt and Samanta, focuses on the 'chars' that are constantly appearing and disappearing in 'the shallow riverbeds in the lower Gangetic plains of deltaic Bengal'. 'Nomadic chars', sandy islands and riverbank accretions that come into being as the result of the combined forces of erosion and sedimentation, provide homes for 'river-gypsies', 'wandering peoples' who 'inhabit a nonlegal, illegible, ungoverned, and ungovernable space, like many other peoples in Asia who have been, in James C. Scott's concise phrase, extruded by coercive state-making' (Lahiri-Dutt and Samanta 2013: ix).

The river ethnography genre also includes numerous shorter journal articles and book chapters. Stephen Lansing, best known for his studies of Balinese irrigation systems (Lansing 1991), has co-authored a study of the Skokomish River in Washington State that compares the ways in which the Indigenous Skokomish people value the river to those of the City of Tacoma, which operates a hydro-power facility on the river (Lansing et al. 1998). Studies of the impact of hydro-electric dams on the relationship of Indigenous peoples to their rivers constitute perhaps the largest single body of literature in the river ethnography genre (e.g. Baviskar 1995; Ettenger 1998; Colombi 2005; Féaux de la Croix 2011; also Muru-Lanning, this volume). Also worth noting, because of its relevance to contributions in this volume by Silverman and Wagner, is a paper by Harrison (2004), which focuses on the ways in which the Manambu people of Papua New Guinea use changes in the course of the Sepik River as a mnemonic device for both remembering and forgetting significant forms of collective experience.

As the 'subjects' of our ethnographic enquiries, we have given rivers free reign in this volume to inspire our imaginations in ways that sometimes converge with, and other times diverge from, the recounted experiences of our interlocutors, the river people who are equally the subjects of our various accounts. Also, though water as subject defies classification as mere $\mathrm{H}_{2} \mathrm{O}$, scarce resource or commodity, we do not abandon our interest in water as resource, but rather attempt to enrich our accounts through an interweaving of different perspectives.

The rivers on which we mainly focus are, of course, only one form of fresh water, and are no more or less important in hydrological terms than lakes, aquifers, springs, glaciers, clouds and precipitation. It is also worth noting that excellent ethnographic studies have been published that feature lakes 
(e.g. Orlove 2002) and estuaries, where fresh and salt water mix (Griffith 1999; Muehlmann 2013). Rivers do possess some unique social and ecological characteristics: the world's largest rivers-the Amazon, Nile, Yangtze, Mississippi, Volga, Ganges and Mekong-drain large portions of entire continents, and typically flow through several countries and thousands of communities on their way to the sea. Each community along the way constructs and reconstructs its own particular sets of relationships with the river-economic, ecological, religious, aesthetic, gendered and differentiated by class, caste and kin group. And the much more numerous, smaller rivers of the world, such as those common throughout Oceania, give rise to similarly diverse and intimate forms of social relations. Smaller, low-elevation islands, mainly coral atolls, often do not have rivers per se, but do have flowing water in the form of small, perhaps seasonal creeks, subterranean water, aquifers and springs. Thus, although we use the term 'rivers' to refer to our subject of study, other forms of flowing fresh water are considered as well.

\section{The Rivers of Oceania}

While descriptions of the sea are prominent in countless studies of Pacific island peoples, many of whom live their lives on ocean and lagoon shores, and who use the maritime domain for subsistence, transport and commerce (e.g. Harding 1967; Hviding 1996; D'Arcy 2006; Hau'ofa 2008), fresh water - a fundamental resource for everyday life everywhere-has remained largely absent from accounts of Pacific island environments and social lives. Only recently have the water resources of the Pacific Islands become a subject of some interest with regard to their vulnerability to the effects of climate change (Jacka 2009; Lazrus 2009, 2012; Duncan 2011; Rudiak-Gould 2013). In the case of atolls, with their precarious freshwater lenses supporting both people and cultivated crops (particularly swamp taro), thereby allowing for human existence in an environment not otherwise supportive of habitation, the absence of a research focus on the roles of fresh water is truly striking (but see Robertson 2013, 2016). And generally, given that most Pacific Islanders are not atoll dwellers, but for the most part live close to rivers, one might assume that ethnographers would have given more attention to rivers and what they provide in both material and symbolic terms. It is a great surprise then that scholarly attention has not been given to people's lives 
with rivers, even in New Guinea, which is one of the world's largest islands, with distinctive groups settled along the coast, by the rivers and in the valleys, hills and mountains of the interior. ${ }^{3}$

In the high islands of the Pacific, including those in the Melanesian archipelagos that approach the scale of small oceanic continents, and in some cases have substantial inland populations, the rivers that flow down from the central mountain ranges are of sufficient cultural significance to warrant closer ethnographic attention. Throughout the high islands of the tropical Pacific (excluding Papua New Guinea), there are far fewer people living inland than there were in pre-colonial times, yet some islands still have extensive settlements in the interior and provide reminders of a Pacific past when inland groups interacted with coastal groups in many different ways. These interactions were often structured according to economic specialisation, but also involved warfare as well as exchange, with rivers as a major scene for such interactions (Ross 1973; Gewertz 1983; Pomponio 1992; Lipset 1997; Bayliss-Smith et al. 2003). Today, rivers still represent important dimensions of everyday life, since they afford spatial mobility in the island topography and easy access to island interiors and their resources. Their headwaters and hilly tributaries provide water supplies for taro irrigation, and they are sources for the seasonal harvest of prized migratory fish species such as mullets. Most immediately, for those Pacific Islanders who do not live with the vulnerable groundwater sources on atolls and raised coral islands, it is the large and small watercourses in the hilly landscape of volcanic islands that provide for robust and stable supplies of often clean, high-quality water for drinking and other household uses in situations of typically high rainfall.

However, as Hviding emphasises in Chapter 2, rivers and fresh water occupy a significant place in the cosmological as well as material lives of Pacific Islanders. The Solomon Islanders whom he describes consider sea water and fresh water as opposing principles, and organise a good deal of their social and religious lives around that opposition. In that setting, large rivers descend from the dark and densely forested terrain of inland peoples and are perceived as inhospitable by those who live on the coast. Other contributors to this volume, while not focusing explicitly on this opposition, note its presence in their own Pacific island settings, but also indicate that it is constructed quite differently between one setting

3 The notable exception is anthropological work done along the mighty Sepik River (e.g. Gewertz 1983; Harrison 2004), which is itself constitutive of large-scale regional systems of exchange. 
and another. Ultimately, as several contributors emphasise, the mouths of rivers are where fresh and salt waters mingle, and where particularly rich and biodiverse aquatic environments come into being. Thus, while many of the inland peoples of large Melanesian islands can accurately be described as river people, like the Eastern Iatmul of the Sepik River in Papua New Guinea (Silverman, this volume), engagements with rivers elsewhere in Oceania do not define people as 'riverine' but are a more or less integral part of everyday life.

This volume is unique by virtue of its focus on the riverine adaptations of Pacific island peoples, and in that sense can be said to fill a gap in the ethnographic record. But the gap is much too large to be filled by a single collection of papers. We hope it will encourage other scholars of Oceania to pay more attention to rivers and fresh water in the future, not just as a contribution to Oceanic literature, but as a uniquely positioned body of knowledge with relevance to other river and river mouth peoples around the world. In addition to the previously mentioned studies of the economic, political and cosmological characteristics of human/river relations, this volume also demonstrates the value and need for studies that examine their ontological, toponymic and linguistic characteristics. Ontological approaches necessarily raise questions about the place of nature in culture, as well as the place of water. Cronon's (1992) significant insights into the role of disciplinary narratives regarding 'nature' in the shaping of research agendas, and in choices about the objects scrutinised within those agendas, seem as relevant to one discipline as to another, and are certainly worth tracking in an interdisciplinary shift towards ontology.

Toponymy, the study of place names, offers particularly rich insights for those interested in studying fresh water from an ontological perspective. Place names provide insights into the eco-social anchoring of identity and social memory in watery sites, while also shedding light on the diverse ways in which such sites are categorised on the basis of diverse sets of values and experiences - whether economic, religious, historic or aesthetic. Place names often serve as anchors for the traditional histories through which knowledge, identity and social practices are transferred from one generation to the next. The study of place names also provides an entry point for the comparative study of water 'languages'- that is to say, the lexicon of water-related terms that at some levels are fairly consistent across large language families such as the Austronesian family, widely distributed throughout Oceania, but are also very localised, rooted in the particular circumstances, history and adaptation of a place-based 
speech community. In addition to the themes and approaches already identified, several authors in this volume address the distinction between flowing and blocked or still waters. Jacka, for instance, writing about the Porgeran people of Papua New Guinea (in Chapter 5), notes that flowing and still waters are seen as opposites, and that still waters are associated with blockages and illness, while flowing water is associated with health. The theme of blockages is addressed most explicitly by Mawyer in his account (in Chapter 4) of lost springs on Mangareva Island in Eastern Polynesia. In that setting, springs are no longer located where local knowledge holders expect them to be, whether because of blockages to intergenerational flows of knowledge or blockages and rerouting of subterranean flows of water. The opposition between blocked and flowing waters, like that between sea water and fresh water, emerges, in fact, as one of the primary themes interwoven throughout the different chapters. Muru-Lanning does not use the term 'blockage' in Chapter 6, but describes a situation in which multiple dams have been built on the Waikato River in order to generate hydro-power, thus blocking the natural flow of a river the Māori consider to be their Tupuna Awa ('River Ancestor'). Some Māori now find themselves in the difficult position of having to decide between becoming shareholders in privatised power companies created through the neo-liberal policies of the national government, which could possibly threaten their customary rights to rivers, or reject shareholder status in order to retain their more traditional guardianship relation, which is bound up with a spiritual and moral duty of care.

It is not surprising that the concept of flow emerged as a recurrent theme throughout this volume, given its prominence in other publications on water. Edgeworth (2011) has written an entire monograph on the Archaeology of Flow, pointing out the numerous ways in which rivers leave traces of their 'entanglements' with past human societies and constitute a form of cultural artefact. 'Flowing waters', he writes, also provide 'models for understanding other kinds of landscape flows' (Edgeworth 2011: 136), a comment reminiscent of Ingold's use of the concept of 'material flows'. Krause (2010: 264) has proposed that we should 'reclaim' the term 'flow' from its dominant use by anthropologists to refer to processes of globalisation, and instead deploy it, metaphorically and materially, to describe 'a world constituted by movement' (see also Mazzullo and Ingold 2008: 34-7; Linton 2010). Many scholars find water 'good to think', as Strang (2014: 134) has emphasised, and the concept of flow appears central to an ever-proliferating number of theoretical approaches. It is 
probably too late, as Féaux de la Croix (2014: 98) argues in response to Krause, to limit the use of this trope in the manner he suggests, but she does see another possible reason to limit its use. '[The] imagery of flow works beautifully for talking about certain kinds of connections', she writes, but ' [it] works less well for talking about disconnection, inequality, injustice' (ibid.: 99). Several authors in this volume find, however, that the concept of blockage — the reverse of flow—does provide a useful way of discussing disconnection.

In the Waikato case study (Chapter 6), blockages of water are associated with commodification, another important theme interwoven throughout the volume. Muru-Lanning, interestingly, discusses commodification in the terms proposed by Kopytoff (1986), who discusses the tendency for objects to move into and out of states of commodification, depending on their cultural, historical and economic context. He uses slaves as his main example, noting that people can be captured, transformed into a commodity through sale in a slave market, but later on returned to nonslave status, at least under some circumstances. Kopytoff's juxtaposition of slavery with commodification is suggestive of another line of reasoning, one he did not pursue but which may still be relevant to our topic. The development aspirations of Pacific Islanders have been described in many publications, in both quotidian and archetypical contexts. ${ }^{4}$ Given water's long history as an instrument of development, it is not surprising that water resources figure prominently in the development processes with which Pacific Islanders are now grappling. In situations where people feel desperate for development and are willing to risk their lives to achieve it, do they not become slaves of another kind, slaves of modernity, captured by processes of commodification that alienate them from the physical environment in which they live and from the products of their own labour (Graeber 2011)? This is a prominent issue throughout the island Pacific and all authors in this volume address it in one way or another. As Illich (1985) writes, contemporary industrial uses of water create a substance that is quite fundamentally different from the wild, flowing, archetypal waters that humans recognise as ancestors or the abode of ancestors, as healing or mysterious, and as the very source of life.

4 For example, see Lindstrom (1993) and Kaplan (1995) on cargo cults, and Errington and Gewertz (2004) on 'Yali's question'. 


\section{Organisation of the Book}

In Chapter 2, our first case study, Edvard Hviding describes the coastal peoples of New Georgia Island, one of the larger volcanic islands in the Solomon island chain. River and sea, fresh water and salt water are 'foundational opposites' in this setting, and associated with them are other oppositions, most notably that between crocodile and shark. For the saltwater people of Marovo Lagoon, the large muddy rivers of New Georgia Island are a 'hostile realm' leading away from an open sunlit shore and lagoon to a dark, unknown and mountainous interior. Hviding thus provides us with a classic coastal Pacific island perspective on rivers, one that is shared, though with considerable variation, across Oceania. Having established the historical nature and cosmological significance of these classic oppositions, he concludes with the description of a newly constructed piped water system that now carries water from a New Georgia river across a lagoon to a small coral island offshore, an innovation that confounds and reconfigures classic oppositions in interesting ways. The piped water system is a practical convenience but also serves as a marker of modernity in this setting. So, in this chapter, we begin our examination of the relationship of development and modernity in Oceania to human/water relations.

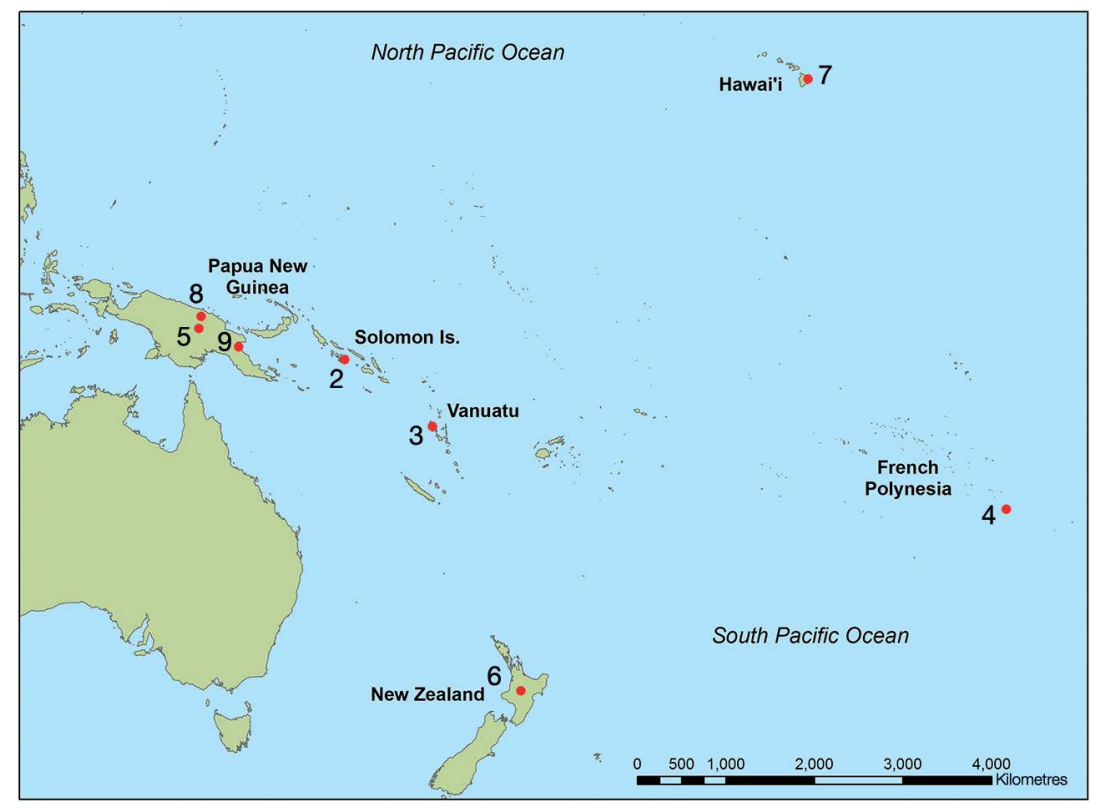

Figure 1.1 Map of the Pacific Ocean, showing locations by chapter.

Source: Cartography by Jerry Jacka. 
In Chapter 3, Carlos Mondragón describes the layered historical meanings of the Jordan River on Espiritu Santo Island, the largest river in the Vanuatu archipelago. The Jordan drains northwards through a sparsely populated region of the island before emptying into Big Bay and the Pacific Ocean. Although he notes the opposition of 'bush' to coastline in this setting, the opposition is muted by comparison to that described by Hviding. However, a saltwater spring located near Big Bay gives rise to a small creek that flows into the bay and is considered 'opposite and complementary to the source of fresh water from which the River Jordan springs'. Mondragón also begins our discussion of freshwater toponymy, which is the study of place names in relation to the cultural identities of particular village sites and kin groups. In the North Santo setting he describes, place names reveal a rich, long-term though mutable set of historical relationships of particular kin groups to particular places and resources within the Jordan River watershed. Christian meanings, as indicated by the current English name of the river, simply add one more layer of meaning to an already complex tapestry.

In Chapter 4, Alex Mawyer also investigates the meanings of place names in his study of the Gambier Islands in Eastern Polynesia while introducing the reader to the richness of Polynesian and Austronesian vocabularies with respect to fresh water. On Mangareva, the largest of the Gambier Islands, certain springs are closely associated with myths and the historical practices of island chiefs. The intergenerational transmission of knowledge about these springs is being lost, however, and in many cases the springs themselves no longer exist in their former locations. Have the springs moved due to hydrological blockages of underground flows? Or is it just the intergenerational transmission of knowledge that has been blocked? Or perhaps both? Mawyer thus introduces us to one of the major themes that runs throughout the book, noting both the material and symbolic aspects of blockages and their contrast with perceptions of free-flowing water. He avoids easy generalisations about the association of blockages and other forms of human interference in water flows with particular historical events-whether the original peopling of Polynesia or the more recent push towards modernity. The theme of blockages proves to be a fertile one for the volume as a whole but one susceptible to varied applications and interpretations.

The theme of blockages is also prominent in Chapter 5, in Jerry Jacka's description of the impact of gold mining on the Porgera River in Papua New Guinea. The Porgeran people are located well inland, far from the 
coast, and here the main opposition is not between salt and fresh water but between moving and still waters, and more generally between movement and stasis. Movement of fluids in the body is associated with health, whereas blockages are associated with illness. Tailings from the Porgera gold mine are dumped directly, untreated, into the Porgera River, one of only four locations in the world where this is permitted, with disastrous results for local communities. Borrowing from Foster (2000), Jacka uses the concept of a metabolic rift to characterise the impact of the mine on Porgeran culture, kinship structures and livelihood strategies. Jacka also shows how rivers shape oppositional social identities as Porgerans and non-Porgerans struggle over access to mineral-rich lands.

In Chapter 6, Muru-Lanning describes the relationship of Māori communities in New Zealand to the Waikato River. This continues the theme of industrialisation begun by Jacka but in the context of hydropower generation rather than mining. Once again, we are dealing with inland communities whose social structures and cosmology owe a great deal to the river along which they live, and Muru-Lanning provides a detailed description of these relations. In this case, however, the focus is on the ways in which commodification and privatisation have confounded traditional relationships. Traditionally, the Māori consider the Waikato, like the Whanganui, to be their Tupuna Awa, or River Ancestor, a relationship incompatible with the commodification of the river for hydro-electricity generation, and also incompatible with the system of European property rights imposed on the Māori through the much earlier Treaty of Waitangi. As in Chapter 3, we see that historical transformations of river relations involve the steady accretion and layering of meanings rather than the simple displacement of one set of meanings by another.

Eilin Torgersen, in Chapter 7, provides us with another classic example of how rivers throughout the world are being commodified for sale in global marketplaces, in this case through tourism rather than hydro-power or mining. 'Tourists come to Hawai' $i$ ', Torgersen writes, 'searching for the perfect waterfall that dives into a refreshing freshwater pool, surrounded by lush vegetation and beautiful flowers - a perfect scene for romance or adventurous cliff-diving activities'. Nevertheless, she continues, 'their dream of paradise is often shattered when the local population or their tour guide warns them about dangerous currents, sharp subsurface rocks and what a pounding 50-metre high waterfall will do to your head if you stand under it'. In her account of the Wailuku River that empties into the 
Pacific Ocean at Hilo on the Big Island, she demonstrates just how much Indigenous ideas about the river differ from tourist representations, and argues that many native Hawaiians deliberately exaggerate the dangers associated with the rivers in order to limit tourist incursions. None of the other chapters engage with forms of impression management as directly as Torgersen, but her approach highlights an important theme that runs throughout the collection. The value and meaning of flowing waters is continually subject to negotiation and strategic deployment within and among communities.

None of the peoples described in this volume have a deeper historical or mythological attachment to their river than the Eastern Iatmul have to the Sepik River, as described by Eric Silverman in Chapter 8. The theme of economic development is as prominent in this chapter as in those that address the uses of rivers for hydro-power generation, tailings disposal and tourism, but in this case the relationship is inverted. The residents of Tambunum village have begun to view their river as an impediment rather than a pathway to development. Even though it is subject to largescale flooding, it is unsuitable for hydro-development and is experiencing a diminishing tourist trade. 'Other regions of Papua New Guinea benefit from petroleum, natural gas, gold, and copper. But the people of Tambunum say that they "only have water and fish".' And even the fisheries are relatively unproductive. River identity, long a matter of pride for communities like Tambunum, is now a symbol of underdevelopment, backwardness and poverty. This chapter is especially telling in its depiction of a people's aspirations for modernity and the conflict between those aspirations and their historic appreciation of their river identity.

Wagner concludes the volume with a chapter that interprets landscape and knowledge transformations as processes of memory and forgetting. Four rivers dominate the social and economic lives of the people of Kamu Yali in Papua New Guinea, but the values and meanings associated with those rivers are subject to continual transformation. Kamu Yali residents selectively remember and forget specific practices, relationships and forms of knowledge about their rivers as they value them alternately as hunting and fishing resources, the ideal location for food gardens, as the source of building materials, fresh water or, most recently, as chromium mining sites. Wagner speaks to many of the same themes as the other contributors - to the ways in which kin group identities are constructed through relationships to specific rivers, to blockages, commodification, industrialisation and metabolic rifts, to the ways in which river relationships are transformed by the inexorable push towards modernity. 
But he also provides a metanarrative for the volume as a whole-one that foregrounds the enduring significance of fresh and flowing water as a subject for contemporary ethnography and emphasises the mimetic relationship of culture to flowing water.

\section{References}

Anderson, D.G., 2000. Identity and Ecology in Arctic Siberia: The Number One Reindeer Brigade. Oxford: Oxford University Press.

Appadurai, A. (ed.), 1986. The Social Life of Things: Commodities in Cultural Perspective. Cambridge: Cambridge University Press. doi.org/10.1017/ CBO9780511819582

Bachelard, G., 1999. Water and Dreams: An Essay on the Imagination of Matter (3rd edition, transl. E.R. Farrell). Dallas (TX): Dallas Institute of Humanities and Culture.

Bakker, K., 2003. An Uncooperative Commodity: Privatizing Water in England and Wales. Oxford: Oxford University Press.

Barnes, J., 2014. Cultivating the Nile: The Everyday Politics of Water in Egypt. Durham (NC): Duke University Press. doi.org/10.1215/9780822376217

Baviskar, A., 1995. In the Belly of the River Tribal Conflicts over Development in the Narmada Valley. Delhi: Oxford University Press.

(ed.), 2007. Waterscapes: The Cultural Politics of a Natural Resource. New Delhi: Permanent Black.

Bayliss-Smith, T., E. Hviding and T. Whitmore, 2003. 'Rainforest Composition and Histories of Human Disturbance in Solomon Islands.' Ambio 32: 346352. doi.org/10.1579/0044-7447-32.5.346

Bennett, J., 2010. Vibrant Matter: A Political Economy of Things. Durham (NC): Duke University Press.

Brown, J.S. and P. Duguid, 2000. The Social Life of Information. Cambridge (MA): Harvard Business School Press.

Carse, A., 2010. 'Editor's Introduction.' Cultural Anthropology (virtual issue on 'Water'). Viewed 7 April 2017 at: production.culanth.org/curated_collections/ 10 -water 
Colombi, B.J., 2005. 'Dammed in Region Six: The Nez Perce Tribe, Agricultural Development, and the Inequality of Scale.' American Indian Quarterly 2: 560-589. doi.org/10.1353/aiq.2005.0085

Cowan, B., 2005. The Social Life of Coffee: The Emergence of the British Coffeehouse. New Haven (CT): Yale University Press.

Crate, S.A. and M. Nuttall (eds), 2009. Anthropology and Climate Change: From Encounters to Actions. Walnut Creek (CA): Left Coast Press.

Cronon, W., 1992. 'A Place for Stories: Nature, History, and Narrative.' Journal of American History 78: 1347-1376. doi.org/10.2307/2079346

D'Arcy, P., 2006. The People of the Sea: Environment, Identity and History in Oceania. Honolulu: University of Hawai'i Press.

Davis, W., 1996. One River: Explorations and Discoveries in the Amazon Rainforest. New York: Simon \& Schuster.

- 2013. River Notes: A Natural and Human History of the Colorado. Washington (DC): Island Press.

Donahue, J. and B.R. Johnston (eds), 1997. Water, Culture and Power: Local Struggles in a Global Context. Washington (DC): Island Press.

Duncan, D., 2011. 'Freshwater under Threat-Pacific Islands: Vulnerability Assessment of Freshwater Resources to Environmental Change.' Bangkok: United Nations Environment Programme.

Edgeworth, M., 2011. Fluid Pasts: Archaeology of Flow. London: Bloomsbury.

Emmons, G.T., 1912. 'The Kitselas of British Columbia.' American Anthropologist 14: 467-471. doi.org/10.1525/aa.1912.14.3.02a00030

Errington, F.K. and D.B. Gewertz, 2004. Yalis Question: Sugar, Culture, and History. Chicago: University of Chicago Press.

Ettenger, K., 1998. “'A River That Was Once So Strong and Deep”: Local Reflections on the Eastmain Diversion, James Bay Hydroelectric Project.' In J. Donahue and B.R. Johnston (eds), Water, Culture and Power: Local Struggles in a Global Context. Washington (DC): Island Press.

Féaux de la Croix, J., 2011. 'Moving Metaphors We Live By: Water and Flow in the Social Sciences and around Hydroelectric Dams in Kyrgyzstan.' Central Asian Survey 30: 487-502. doi.org/10.1080/02634937.2011.614097

_ 2014 . 'Everybody Loves Flow': On The Art Of Rescuing A Word From Its Users. Suomen Antropologi 39(2): 97-99. 
Feld, S., 1996. 'Waterfalls of Song: An Acoustemology of Place Resounding in Bosavi, Papua New Guinea.' In S. Feld and K.H. Basso (eds), Senses of Place. Santa Fe (NM): School of Advanced Research Seminar Series.

Foster, J.B., 2000. Marx's Ecology: Materialism and Nature. New York: Monthly Review Press.

Geertz, C., 1972. 'The Wet and the Dry: Traditional Irrigation in Bali and Morocco.' Human Ecology 1: 23-39. doi.org/10.1007/BF01791279

Gewertz, D.B., 1983. Sepik River Societies: A Historical Ethnography of the Chambri and Their Neighbors. New Haven (CT): Yale University Press.

Goldman, I., 1963. The Cubeo: Indians of the Northwest Amazon. Urbana (IL): University of Illinois Press.

Graeber, D., 2011. Debt: The First 5,000 Years. Brooklyn (NY): Melville House.

Griffith, D., 1999. The Estuary's Gift: An Atlantic Coast Cultural Biography. University Park: Pennsylvania State University Press.

Harding, T.G., 1967. Voyagers of the Vitiaz Strait: A Study of a New Guinea Trade System. Seattle (WA): University of Washington Press.

Harris, M., 2001. Life on the Amazon: The Anthropology of a Brazilian Peasant Village. London: British Academy.

Harrison, S., 2004. 'Forgetful and Memorious Landscapes.' Social Anthropology 12: 135-151. doi.org/10.1017/S0964028204000436

Hastrup, K.B. (ed.), 2009. The Question of Resilience: Social Responses to Climate Change. Copenhagen: Danish Royal Society of Sciences and Letters.

— , 2012. 'The Social Life of Science.' Public Service Review: Science and Technology 15: 90-91.

Hastrup, K.B. and F. Hastrup (eds), 2016. Waterworlds: Anthropology in a Fluid World. New York (NY): Berghahn Books.

Hastrup, K.B. and M. Skrydstrup, 2013. The Social Life of Climate Change Models: Anticipating Nature. New York (NY): Routledge.

Hau'ofa, E., 2008. We Are the Ocean: Selected Works. Honolulu: University of Hawai'i Press.

Hayes, A.J., 1906. The Source of the Blue Nile: A Record of a Journey Through the Soudan to Lake Tsana in Western Abyssinia, and of the Return to Egypt, by the Valley of the Atbara, with a Note on the Religion, Customs, or. of Abyssinia. London: Smith, Elder \& Co. 
Helmreich, S., 2009. Alien Ocean: Anthropological Voyages in Microbial Seas. Berkeley (CA): University of California Press.

Holmes, T.V., 1898. 'On the Evidence for the Efficacy of the Diviner and His Rod in the Search for Water.' Journal of the Anthropological Institute of Great Britain and Ireland 27: 233-259. doi.org/10.2307/2842965

Hongi, H., 1894. 'The Contest between Fire and Water.' Journal of the Polynesian Society 3: 155-158.

Hossen, A.M., 2014. Water Policy and Governance for the Empowerment of River Basin Communities in Rural Bangladesh. Okanagan: University of British Columbia (PhD thesis).

Hviding, E., 1996. Guardians of Marovo Lagoon: Practice, Place, and Politics in Maritime Melanesia. Honolulu: University of Hawai'i Press (Pacific Islands Monograph 14).

Illich, I., 1985. $\mathrm{H}_{2} \mathrm{O}$ and the Waters of Forgetfulness: Reflections on the Historicity of 'Stuff. Dallas (TX): Dallas Institute of Humanities and Culture.

Ingold, T., 2006. 'Rethinking the Animate, Re-animating Thought'. Ethnos 71(1): 9-20. doi.org/10.1080/00141840600603111

— , 2010. 'The Textility of Making.' Cambridge Journal of Economics 34: 91102. doi.org/10.1093/cje/bep042

Jacka, J., 2009. 'Global Averages, Local Extremes: The Subtleties and Complexities of Climate Change in Papua New Guinea.' In S. Crate and M. Nuttall (eds), Anthropology and Climate Change: From Encounters to Actions. Walnut Creek (CA): Left Coast Press.

Kaplan, M., 1995. Neither Cargo nor Cult: Ritual Politics and the Colonial Imagination in Fiji. Durham (NC): Duke University Press. doi.org/ $10.1215 / 9780822381914$

Kopytoff, I., 1986. 'The Cultural Biography of Things: Commoditisation as Process.' In A. Appadurai (ed.), The Social Life of Things: Commodities in Cultural Perspective. Cambridge: Cambridge University Press. doi.org/10.1017/CBO9780511819582.004

Krause, F., 2010. Thinking Like a River: An Anthropology of Water and its Uses along the Kemi River, Northern Finland. Aberdeen: University of Aberdeen (PhD thesis).

_ 39: 89-91. 
Krause, F. and V. Strang, 2016. 'Thinking Relationships through Water.' Society \& Natural Resources 29: 633-638. doi.org/10.1080/08941920.2016.1151714

Lahiri-Dutt, K. and G. Samanta, 2013. Dancing with the River: People and Life on the Chars of South Asia. New Haven (CT): Yale University Press. doi.org/ $10.12987 /$ yale/9780300188301.001.0001

Lansing, J.S., 1991. Priests and Programmers: Technologies of Power in the Engineered Landscape of Bali. Princeton (NJ): Princeton University Press.

Lansing, J.S., P.S. Lansing and J. Erazo, 1998. 'The Value of a River.' Journal of Political Ecology 5: 1-22. doi.org/10.2458/v5i1.21395

Lazrus, H., 2009. 'The Governance of Vulnerability: Climate Change and Agency in Tuvalu, South Pacific'. In S. Crate and M. Nuttal (eds), Anthropology and Climate Change: From Encounters to Actions. Walnut Creek, CA: Left Coast Press.

— 2012. 'Sea Change: Island Communities and Climate Change.' Annual Review of Anthropology 41: 285-301. doi.org/10.1146/annurev-anthro092611-145730

Lindstrom, L., 1993. Cargo Cult: Strange Stories of Desire from Melanesia and Beyond. Honolulu: University of Hawai'i Press.

Linton, J., 2010. What Is Water? The History of a Modern Distraction. Vancouver: UBC Press.

Lipset, D., 1997. Mangrove Man: Dialogics of Culture in the Sepik Estuary. Cambridge: Cambridge University Press. doi.org/10.1017/CBO 9781139166867

Mazzullo, N. and T. Ingold, 2008. 'Being Along: Place, Time and Movement among Sa'mi People.' In O.B. Jøren and B. Grana (eds), Mobility and Place: Enacting Northern European Peripheries. Aldershot: Ashgate.

Mehta, L., 2005. The Politics and Poetics of Water: Naturalizing Scarcity in Western India. Hyderabad: Orient Longman.

Mosse, D., 2003. The Rule of Water: Statecraft, Ecology, and Collective Action in South India. Oxford: Oxford University Press.

Muehlmann, S., 2013. Where the River Ends: Contested Indigeneity in the Mexican Colorado Delta. Durham (NC): Duke University Press. doi.org/10.1215/ 9780822378846

Murray, J.W.P. and S.H. Ray, 1918. 'The People and Language between the Fly and Strickland Rivers, Papua.' Man 18: 40-45. doi.org/10.2307/2788423 
Orlove, B., 2002. Lines in the Water: Nature and Culture at Lake Titicaca. Berkeley: University of California Press.

, 2009. 'The Past, the Present and Some Possible Futures of Adaptation.'

In W.N. Adger, I. Lorenzoni and K. O'Brien (eds), Adaptation to Climate Change: Thresholds, Values, Governance. Cambridge: Cambridge University Press. doi.org/10.1017/CBO9780511596667

Orlove, B. and S.C. Caton, 2010. 'Water Sustainability: Anthropological Approaches and Prospects.' Annual Review of Anthropology 39: 401-415. doi.org/10.1146/annurev.anthro.012809.105045

Piddington, R., 1930. 'The Water-Serpent in Karadjeri Mythology.' Oceania 1: 352-354. doi.org/10.1002/j.1834-4461.1930.tb01656.x

Pomponio, A., 1992. Seagulls Don't Fly into the Bush: Cultural Identity and Development in Melanesia. Belmont (CA): Wadsworth.

Raffles, H., 2002. In Amazonia: A Natural History. Princeton (NJ): Princeton University Press.

Rival, L., 1998. The Social Life of Trees: Anthropological Perspectives on Tree Symbolism. Oxford: Berg.

Robertson, M.L., 2013. Connecting Worlds of Water: An Ethnography of Environmental Change on Tarawa, Kiribati. Copenhagen: University of Copenhagen ( $\mathrm{PhD}$ thesis).

— 2016. 'Enacting Groundwaters in Tarawa, Kiribati: Searching for Facts and Articulating Concerns.' In K. Hastrup and F. Hastrup (eds), Waterworlds: Anthropology in Fluid Environments. New York: Berghahn Books.

Ross, H.M., 1973. Baegu: Social and Ecological Organization in Malaita, Solomon Islands. Chicago: University of Illinois Press.

Rudiak-Gould, P., 2013. Climate Change and Tradition in a Small Island State. London: Routledge.

Salmond, A., 2014. 'Tears of Rangi: Water, Power, and People in New Zealand.' HAU: Journal of Ethnographic Theory 4: 285-309. doi.org/10.14318/ hau4.3.017

Smith, S.P., 1913. The Lore of the Whare Wananga (2 volumes). New Plymouth (NZ): The Polynesian Society.

Steward, J.H., 1949. 'Cultural Causality and Law: A Trial Formulation of the Development of Early Civilizations.' American Anthropologist 51: 1-27. doi.org/10.1525/aa.1949.51.1.02a00020 
Steward, J.H., R. McAdams, M.D. Collier, A. Palerm, K.A. Wittfogel and R. Beals, 1955. Irrigation Civilizations: A Comparative Study. Washington (DC): Pan American Union (Social Science Monograph 1).

Strang, V., 2004. The Meaning of Water. Oxford: Berg.

—, 2009. Gardening the World: Agency, Identity and the Ownership of Water. New York: Berghahn Books.

__ 2014. 'Fluid Consistencies: Material Relationality in Human Engagements.' Archaeological Dialogues 21: 133-150. doi.org/10.1017/S1380203814000130

— , 2016. 'Reflecting Nature: Water Beings in History and Imagination.' In K. Hastrup and F. Hastrup (eds), Waterworlds: Anthropology in Fluid Environments. New York (NY): Berghahn Books.

Sultana, F. and A. Loftus (eds), 2012. The Right to Water: Politics, Governance and Social Struggles. New York (NY): Earthscan.

Urton, G., 2010. The Social Life of Numbers: A Quechua Ontology of Numbers and Philosophy of Arithmetic. Austin (TX): University of Texas Press.

Wagner, J., 2012. 'Water and the Commons Imaginary.' Current Anthropology 53: 617-641. doi.org/10.1086/667622

— (ed.), 2013. The Social Life of Water. New York (NY): Berghahn Books.

Weir, J.K., 2009. Murray River Country: An Ecological Dialogue with Traditional Owners. Canberra: Aboriginal Studies Press.

Whiteford, L. and S. Whiteford, 2005. Globalization, Water and Health: Resource Management in Times of Scarcity. Santa Fe (NM): School of American Research Press.

Wittfogel, K.A., 1956. The Hydraulic Civilizations. Chicago (IL): University of Chicago Press.

—, 1957. Oriental Despotism: A Comparative Study of Total Power. New Haven (CT): Yale University Press.

Worster, D., 1985. Rivers of Empire: Water, Aridity and the Growth of the American West. New York (NY): Pantheon. 
This text is taken from Island Rivers: Fresh Water and Place in Oceania, edited by John R. Wagner and Jerry K. Jacka, published 2018 by ANU Press, The Australian National University, Canberra, Australia.

doi.org/10.22459/IR.06.2018.01 